\title{
PENGARUH BUDAYA ORGANISASI, BEBAN KERJA DAN DISIPLIN KERJA TERHADAP PRODUKTIVITAS KERJA KARYAWAN PADA CV. AKADEMI MANDIRI MEDAN
}

\section{Fadzil Hanafi Asnora}

Dosen Fakultas Ekonomi dan Bisnis Universitas Labuhanbatu Email: hanafi.asnora91@gmail.com

\begin{abstract}
Abstrak
Setiap organisasi akan selalu berupaya agar para anggota atau karyawan yang terlibat dalam kegiatan organisasi dapat memberikan prestasi dalam bentuk produktivitas kerja setinggi mungkin untuk mewujudkan tujuan yang telah ditetapkan sebelumnya. Merealisasikan produktivitas kerja merupakan hal yang sangat penting bagi birokrasi, karena dengan adanya produktivitas kerja diharapkan pekerjaan akan terlaksana secara efektif dan efisien, sehingga ini semua akhirnya sangat diperlukan dalam pencapaian tujuan. Beban kerja juga mempengaruhi produktivitas kerja karyawan. Hal ini disebabkan beban kerja yang diberikan kepada karyawan sering kali tidak sesuai dengan keterampilan maupun keahlian yang dimilikinya. Membangun budaya organisasi tentu tidak semudah mengucapkannya, harus melalui suatu proses lama dan berkelanjutan. Disebut berkelanjutan karena nilai-nilai dan norma-norma yang terkandung dalam budaya tersebut terus menerus mengalami perubahan dan berkembang sesuai dengan zamannya. Sikap disiplin yang tinggi sangat diperlukan demi tercapainya tujuan organisasi. Oleh karena itu sangat diharapkan bahwa setiap karyawan memiliki sikap disiplin yang tinggi dalam melaksanakan kewajibankewajibannya sehingga produktivitas kerjanya pun dapat meningkat. Jumlah sampel dalam penelitian ini adalah berjumlah 93 orang dengan menggunakan teknik sampel jenuh. Teknik analisis yang digunakan adalah regresi linier berganda. Teknik analisis yang digunakan adalah regresi linier berganda. Hasil penelitian menunjukkan bahwa secara bersama-sama variabel budaya organisasi, beban kerja dan disiplin kerja berpengaruh signifikan terhadap produktivitas kerja karyawan. Beban kerja tidak berpengaruh signifikan terhadap produktivitas kerja karyawan, budaya organisasi berpengaruh signifikan terhadap produktivitas kerja karyawan serta disiplin kerja berpengaruh signifikan terhadap produktivitas kerja karyawan.
\end{abstract}

\section{Kata kunci : Budaya Organisasi, Beban Kerja, Disiplin Kerja, Produktivitas Kerja Karyawan}

\section{PENDAHULUAN}

\section{Latar Belakang Penelitian}

Setiap organisasi akan selalu berupaya agar para anggota atau karyawan yang terlibat dalam kegiatan organisasi dapat memberikan prestasi dalam bentuk produktivitas kerja setinggi mungkin untuk mewujudkan tujuan yang telah ditetapkan sebelumnya. Merealisasikan produktivitas kerja merupakan hal yang sangat penting bagi birokrasi, karena dengan adanya produktivitas kerja diharapkan pekerjaan akan terlaksana secara efektif dan efisien, sehingga ini semua akhirnya sangat diperlukan dalam pencapaian tujuan. Oleh karena itu sangat jelas diketahui bahwa sikap disiplin merupakan hal yang sangat penting dalam pencapaian tujuan organisasi dan apabila sikap disiplin tersebut tertanam dengan baik pada para aparatur 
negara atau karyawan maka akan terwujud pemerintahan yang bersih, adil dan bertanggung jawab serta produktivitas kerja karyawan akan terus meningkat.

Sumber daya manusia merupakan aset terpenting perusahaan karena perannya sebagai pelaksana kebijakan dan kegiatan operasional dalam mencapai tujuan perusahaan, baik untuk memperoleh keuntungan maupun untuk mempertahankan kelangsungan hidup perusahaan. Berhasil tidaknya suatu perusahaan dalam mempertahankan eksistensinya dimulai dari manusia itu sendiri untuk mempertahankan perusahaan dalam meningkatkan efektivitas dan efisiensi secara maksimal. Mengingat demikian pentingnya faktor sumber daya manusia dalam suatu usaha, maka amat perlu bagi seorang pimpinan perusahaan untuk mengoptimalkan tenaga kerja yang dimiliki, agar menghasilkan tenaga kerja yang terampil dan berkualitas sehingga produktivitas perusahaan diharapkan meningkat. Pengembangan sumber daya manusia adalah suatu proses peningkatan kualitas atau kemampuan manusia dalam rangka mencapai suatu tujuan pembangunan bangsa, yang meliputi perencanaan, pengembangan dan pengelolaan sumber daya, karena itu setiap organisasi dituntut lebih proaktif dalam meningkatkan kualitas anggotanya dan menstimulasi mereka agar dapat melaksanakan tugasnya dengan baik sesuai dengan bidangnya masing-masing.

Budaya organisasi dipercaya sebagai perekat dalam organisasi yang mengalami perubahan. Membangun budaya organisasi tentu tidak semudah mengucapkannya, harus melalui suatu proses lama dan berkelanjutan. Disebut berkelanjutan karena nilai-nilai dan norma-norma yang terkandung dalam budaya tersebut terus menerus mengalami perubahan dan berkembang sesuai dengan zamannya. Oleh karena itu budaya organisasi perlu dibangun sedemikian rupa agar fleksibel, adaptif dan akomodatif terhadap aneka perubahan sehingga citacita organisasi yang memiliki keunggulan bukan sekedar impian. Organisasi dengan budaya tertentu memberikan daya tarik bagi individu dengan karakteristik tertentu untuk bergabung. Budaya organisasi bersifat nonformal atau tidak tertulis namun mempunyai peranan penting sebagai cara berpikir, menerima keadaan dan merasakan sesuatu dalam perusahaan tersebut.

Selain budaya organisasi, beban kerja juga mempengaruhi produktivitas kerja karyawan. Hal ini disebabkan beban kerja yang diberikan kepada karyawan sering kali tidak sesuai dengan keterampilan maupun keahlian yang dimilikinya. Fenomena yang ada di dalam perusahaan adanya beban kerja yang tinggi dimana hal ini mengurangi produktivitas kerja karyawan, yang disebabkan kebutuhan dalam hal sarana dan prasarana/infrastruktur belum mendukung karyawan dalam menyelesaikan pekerjaannya. Begitu juga dengan budaya kerja yang kadang tidak sesuai dengan latar belakang pendidikan dan kultur budaya karyawan yang menyebabkan turunnya produktivitas kerja baik secara langsung maupun perlahan-lahan. Dengan beban kerja dan budaya kerja, maka disiplin kerja juga ikut terpengaruh. Dari survei awal yang penulis lakukan selama seminggu dan berdasarkan informasi yang didapat dari salah satu karyawan, masih ditemukan gejala-gejala, seperti masih ada karyawan yang datang terlambat dan pulang lebih cepat, tidak mengikuti briefing, istirahat terlalu lama serta pada saat jam kerja masih ada karyawan yang tidak ada di tempat dengan alasan yang tidak jelas, kurang efektifnya pencapaian hasil kerja dan waktu penyelesaian kerja tidak sesuai dengan waktu yang ditentukan. 
Dari survei awal yang dilakukan, masih ditemukan gejala-gejala, seperti masih ada karyawan yang datang terlambat dan pulang lebih cepat, tidak mengikuti apel pagi, istirahat terlalu lama serta pada saat jam kerja masih ada karyawan yang tidak ada di tempat dengan alasan yang tidak jelas, kurang efektifnya pencapaian hasil kerja dan waktu penyelesaian kerja tidak sesuai dengan waktu yang ditentukan. Gejala-gejala di atas merupakan masalah dalam organisasi karena kurangnya sikap disiplin yang dimiliki masingmasing karyawan. Sikap disiplin yang tinggi sangat diperlukan demi tercapainya tujuan organisasi. Oleh karena itu sangat diharapkan bahwa setiap karyawan memiliki sikap disiplin yang tinggi dalam melaksanakan kewajiban-kewajibannya sehingga produktivitas kerjanya pun dapat meningkat. Berdasarkan uraian di atas, maka penulis memilih judul penelitian yaitu : "Pengaruh Budaya Organisasi, Beban Kerja dan Disiplin Kerja Terhadap Produktivitas Kerja Karyawan Pada CV. Akademi Mandiri Medan".

\section{KAJIAN PUSTAKA}

\section{Kerangka Teoritis \\ Pengertian Produktivitas Kerja}

Menurut Admosoeprapto (2010 : 26) : "Produktivitas adalah ukuran sejauh mana sumber-sumber daya alam, tekhnologi, manusia yang dipergunakan dengan baik dapat mewujudkan hasil tertentu yang diinginkan. Secara singkat produktivitas adalah ukuran mengenai apa yang diperoleh dan apa yang diberikan, seberapa jauh masukan (input) dapat menghasilkan keluaran (output) sesuai dengan standard yang ditetapkan". Menurut Sunyoto (2012 : 203) "Produktivitas adalah ukuran yang menunjukkan pertimbangan antara input dan output yang dikeluarkan perusahaan serta peran tenaga kerja yang dimiliki persatuan waktu". Selanjutnya Saksono (2012 : 122) mengatakan "Produktivitas adalah rasio antara produksi yang dapat dihasilkan dengan keseluruhan biaya yang telah dikeluarkan untuk keperluan produktivitas itu atau rasio antara seluruh kepuasan yang dapat diperoleh dengan pengorbanan yang telah diberikan"

\section{Indikator Produktivitas Kerja Karyawan}

Menurut Kusriyanto (2012 : 43), indikator produktivitas kerja adalah :

a. Keadaan Fisik.

b. Pendidikan.

c. Metode Kerja.

d. Lingkungan Kerja.

e. Sikap dan Kebiasaan.

f. Peralatan yang Digunakan.

\section{Pengertian Budaya Organisasi}

Menurut Williams (2011:84) budaya organisasi adalah seperangkat nilainilai, keyakinan, dan sikap utama yang diberlakukan di antara anggota organisasi. Budaya organisasi sering kali diciptakan oleh pendiri perusahaan, kemudian dipertahankan dengan cara memberitahukan riwayat organisasi dan merayakan kepahlawanan organisasi. Budaya yang dapat menysuaikan dan mendorong keterlibatan karyawan, dapat memperjelas tujuan dan arah startegis organisasi, serta yang senantiasa menguraikan dan mengajarkan nilai-nilai dan keyakinan 
organisasi, dapat membantu perusahaan mencapai pertumbuhan penjualan, pengembalian modal, keuntungan, mutu, dan kepuasan pelanggan yang lebih tinggi. Pengganti perilaku, penambahan perilaku dan perubahan benda-benda perlambang adalah cara-cara yang dapat dilakukan oleh manajer untuk memulai perubahan budaya organisasi.

\section{Indikator Budaya Organisasi}

Menurut Harrison dalam Sobirin (2007:198) ada 4 (empat) indikator budaya organisasi:
a. Power Culture.
b. Role Culture
c. Achievement Culture
d. Support Culture

\section{Pengertian Beban Kerja}

Pengertian beban kerja adalah sejumlah kegiatan yang harus diselesaikan oleh suatu unit organisasi atau pemegang jabatan secara sistematis dengan menggunakan teknik analisis jabatan, teknik analisa beban kerja, atau teknik manajemen lainnya dalam jangka waktu tertentu untuk mendapatkan informasi tentang efisiensi dan efektifitas kerja suatu unit organisasi (Suwatno, 2013).

Menurut Dhania (2010) beban kerja adalah sekumpulan atau sejumlah kegiatan yang harus diselesaikan oleh suatu unit organisasi atau pemegang jabatan dalam jangka waktu tertentu. Berdasarkan beberapa pengertian beban kerja diatas, dapat disimpulkan bahwa beban kerja merupakan suatu rangkaian kegiatan yang harus diselesaikan oleh suatu unit organisasi atau pemegang jabatan dalam jangka waktu tertentu.

\section{Indikator Beban Kerja}

Dimensi beban kerja menurut Suwatno (2013:72) menggunakan indikatorindikator, antara lain :

a. Jam kerja efektif

b. Latar Belakang Pendidikan

c. Jenis pekerjaan yang diberikan

\section{Pengertian Disiplin Kerja}

Pegawai yang disiplin dan menaati tata tertib, menaati semua normanorma dan peraturan yang berlaku dalam organisasi atau instansi akan dapat meningkatkan efisiensi, efektifitas dan produktivitas. Sedangkan organisasi atau intansi yang mempunyai pegawai yang tidak disiplin, akan sulit sekali melaksanakan program-programnya untuk meningkatkan produktivitas, dan akan tidak mungkin untuk dapat merealisasikan pencapaian tujuan yang telah ditetapkan sebelumnya. Oleh sebab itu seorang pemimpin yang baik harus berusaha agar para bawahannya mempunyai disiplin yang baik dan juga harus memberikan contoh dalam menjalankan disiplin yang baik dalam suatu organisasi. Beberapa pengertian disiplin oleh para ahli diantaranya adalah sebagai berikut : Siagian (2007 : 305): "Disiplin adalah suatu bentuk pelatihan yang berusaha memperbaiki dan membentuk pengetahuan, sikap dan perilaku pegawai sehingga 
para pegawai tersebut secara sukarela berusaha bekerja kooperatif dengan para pegawai yang lain serta meningkatkan prestasi kerja".

\section{Indikator Disiplin Kerja}

Menurut Hartatik (2014 : 200), indikator-indikator disiplin kerja adalah sebagai berikut :
a. Tujuan dan kemampuan.
b. Keteladanan pimpinan.
c. Keadilan.
d. Pengawasan Melekat.
e. Sanksi hukum.
f. Ketegasan.
g. Hubungan kemanusiaan..

\section{METODE PENELITIAN}

\section{Jenis Penelitian}

Penelitian ini merupakan penelitian kuantitatif, yaitu penelitian yang bersifat menghubungkan dua variabel atau lebih. Berdasarkan penjelasan di atas, dapat diketahui bahwa penelitian kuantitatif yang bermaksud untuk memberikan penjelasan pengaruh budaya organisasi, beban kerja dan disiplin kerja terhadap produktivitas kerja karyawan.

\section{Teknik Analisis Data Penelitian}

\section{Analisis Regresi Berganda}

Untuk mengetahui pengaruh atau hubungan variabel bebas (budaya organisasi, beban kerja dan disiplin kerja) dengan variabel terikat (produktivitas kerja karyawan), maka akan digunakan metode regresi linier berganda dan analisis data juga menggunakan SPSS, rumusnya adalah sebagai berikut :

$\begin{array}{lll}\mathrm{Y} & =\mathrm{a}+\mathrm{b}_{1} \mathrm{X}_{1}+\mathrm{b}_{2} \mathrm{X}_{2}+\varepsilon \\ \mathrm{y} & = & \text { Produktivitas kerja karyawan } \\ \mathrm{a} & = & \text { nilai } \mathrm{y}, \text { apabila } \mathrm{X}_{1}=\mathrm{X}_{2} \\ \mathrm{~b}_{1}, \mathrm{~b}_{2}, \mathrm{~b}_{3} & = & \text { koefisien regresi berganda } \\ \mathrm{X}_{1} & = & \text { Budaya organisasi } \\ \mathrm{X}_{2} & = & \text { Beban kerja } \\ \mathrm{X}_{3} & = & \text { Disiplin kerja } \\ \varepsilon & = & \text { Standard Error }\end{array}$


HASIL DAN PEMBAHASAN

Hasil Penelitian

\section{Persamaan Regresi \\ Coefisients}

\begin{tabular}{lrrrrr}
\hline \multirow{2}{*}{ Model } & \multicolumn{2}{c}{$\begin{array}{c}\text { Unstandardized } \\
\text { Coefisients }\end{array}$} & $\begin{array}{c}\text { Standardized } \\
\text { Coefisients }\end{array}$ & \multirow{2}{*}{ t } & Sig \\
\cline { 2 - 4 } & \multicolumn{1}{c}{$\mathrm{B}$} & \multicolumn{1}{c}{ Std. Error } & Beta & & \\
\hline (Constant) & 11.127 & 3.258 & & 3.415 & .001 \\
Budaya organisasi & -.264 & .170 & -.147 & -1.556 & .123 \\
Beban kerja & .356 & .140 & .242 & 2.545 & .023 \\
Disiplin kerja & .254 & .079 & .420 & 4.484 & .000 \\
\hline
\end{tabular}

$$
Y=11.127-0.264 X_{1}+0.356 X_{2}+0.354 X_{3}
$$

Koefisien Determinasi

Model Summary

\begin{tabular}{ccccc}
\hline Model & R & R Square & $\begin{array}{c}\text { Adjusted R } \\
\text { Square }\end{array}$ & $\begin{array}{c}\text { Std. Error of } \\
\text { the Estimate }\end{array}$ \\
\hline 1 & .511 & .262 & .237 & 2.96509 \\
\hline
\end{tabular}

Tabel diatas menunjukkan bahwa variabel produktivitas kerja karyawan (y) dipengaruhi oleh variabel $\mathrm{X}_{1}$ (budaya organisasi), variabel $\mathrm{X}_{2}$ (beban kerja) dan variabel $\mathrm{X}_{3}$ (disiplin kerja) secara bersama-sama sebesar $26,2 \%$ dan sisanya sebesar 73,8\% ditentukan oleh variabel lain di luar kontribusi penelitian ini.

\section{Pengujian Hipotesis}

Uji F

\section{Anova}

\begin{tabular}{lrrrrr}
\hline Model & $\begin{array}{c}\text { Sum of } \\
\text { Squares }\end{array}$ & Df & \multicolumn{1}{c}{$\begin{array}{c}\text { Mean } \\
\text { Square }\end{array}$} & F & Sig \\
\hline Regression & 277,232 & 3 & 92.411 & 10.511 &, 000 \\
Residual & 782.467 & 89 & 8.792 & & \\
\hline Total & $\mathbf{1 0 5 9 . 6 9 9}$ & $\mathbf{9 2}$ & & & \\
\hline
\end{tabular}

Data di atas menunjukkan bahwa uji ANOVA diperoleh sebesar 13.719 dengan tingkat signifikansi 0,000 , ( $F_{\text {hitung }}>F_{\text {tabel }}(10.511>3,09)$. Hal ini menunjukkan bahwa secara serempak variabel budaya organisasi, beban kerja dan disiplin kerja berpengaruh signifikan terhadap produktivitas kerja karyawan. Dengan ini dapat disimpulkan bahwa hipotesis dari penelitian ini dapat diterima yaitu : "Budaya organisasi, beban kerja dan disiplin kerja berpengaruh signifikan terhadap produktivitas kerja karyawan (terima Hi dan tolak Ho)”. 
Uji t

Coefisients

\begin{tabular}{lrrrrr}
\hline \multirow{2}{*}{ Model } & \multicolumn{2}{c}{$\begin{array}{c}\text { Unstandardized } \\
\text { Coefisients }\end{array}$} & $\begin{array}{c}\text { Standardized } \\
\text { Coefisients }\end{array}$ & t & Sig \\
\cline { 2 - 4 } & \multicolumn{1}{c}{$\mathrm{B}$} & \multicolumn{1}{c}{ Std. Error } & \multicolumn{1}{c}{ Beta } & & \\
\hline (Constant) & 11.127 & 3.258 & & 3.415 & .001 \\
Budaya organisasi & -.264 & .170 & -.147 & -1.556 & .123 \\
Beban kerja & .356 & .140 & .242 & 2.545 & .023 \\
Disiplin kerja & .254 & .079 & .420 & 4.484 & .000 \\
\hline
\end{tabular}

Dari nilai t-tabel dengan derajat bebas $93-2=91$ dan taraf nyata $5 \%$ adalah 1.986. Nilai t-hitung $b_{1}<t$ t-tabel $(-1.556<1.986)$, maka variabel budaya organisasi tidak berpengaruh signifikan terhadap produktivitas kerja karyawan. Variabel beban kerja yang berpengaruh signifikan terhadap produktivitas kerja karyawan dilihat dari nilai $t_{\text {hitung }}>\mathrm{t}_{\text {tabel }}(2.545>1.986)$. Sedangkan variabel disiplin kerja berpengaruh signifikan terhadap produktivitas kerja karyawan dilihat dari nilai $t_{\text {hitung }}>\mathrm{t}_{\text {tabel }}(4.484>1.986)$

\section{SIMPULAN DAN SARAN}

\section{Simpulan}

1. Budaya organisasi tidak berpengaruh signifikan terhadap produktivitas kerja karyawan

2. Beban kerja berpengaruh signifikan terhadap produktivitas kerja karyawan.

3. Disiplin kerja berpengaruh signifikan terhadap produktivitas kerja karyawan

4. Variabel budaya organisasi, beban kerja dan disiplin kerja berpengaruh signifikan terhadap produktivitas kerja karyawan.

5. Variabel produktivitas kerja karyawan (y) dipengaruhi oleh variabel $\mathrm{X}_{1}$ (budaya organisasi), variabel $\mathrm{X}_{2}$ (beban kerja) dan variabel $\mathrm{X}_{3}$ (disiplin kerja) secara bersama-sama sebesar 26,2 \% dan sisanya sebesar 73,8 \% ditentukan oleh variabel lain di luar kontribusi penelitian ini.

\section{Saran}

1. Dengan beban kerja, diharapkan agar seorang CV. Akademi Mandiri Medan Medan tidak sampai membuat pegawainya stres dalam pekerjaan karena itu akan memberikan pengaruh buruk terhadap motivasi kerja dari pegawai. Semakin berat beban kerja yang diberikan dan tidak sesuai dengan proporsinya, maka akan semakin beratlah pekerjaan tersebut.

2. Saran yang dapat diberikan adalah CV. Akademi Mandiri Medan Medan agar menempatkan pegawai sesuai dengan keahlian masing-masing karena dengan begitu akan meningkatkan motivasi kerja dari pegawai itu sendiri. Seorang pimpinan agar selalu memotivasi pegawainya untuk bekerja karena dengan begitu kepuasan kerja dari pegawai akan meningkat. 


\section{DAFTAR PUSTAKA}

Anita, Julia. Aziz, Nasir dan Yunus, Mukhlis. (2013). Pengaruh Penempatan Dan Beban Kerja Terhadap Motivasi Kerja Dan Dampaknya Pada Prestasi Kerja Pegawai Dinas Tenaga Kerja Dan Mobilitas Penduduk Aceh. Jurnal Manajemen. Pascasarjana Universitas Syiah Kuala. Volume 2, No. 1, November 2013. pp. 67- 77. ISSN 2302-0199.

Diputra, Ida Bagus Gede Surya dan Riana, I Gede. (2014). Pengaruh Budaya Organisasi Dan Kepuasan Kerja Terhadap Motivasi Kerja Karyawan Pada Hard Rock Hotel Bali. E-Jurnal Ekonomi dan Bisnis Universitas Udayana 3.5 (2014) : 276-288. ISSN : 2337-3067

Flippo. B, Edwin, (2013), Manajemen Personalia, Jilid I, Edisi Keenam, Penerbit Erlangga, Yogyakarta.

Handoko, T. Hani, (2013), Manajemen, Edisi Kedua, Cetakan Kesebelas, Penerbit BPFE-Yogyakarta, Yogyakarta.

James A. F. Stoner, (2010), Manajemen, Jilid II, Edisi Kedua, Cetakan Kedua, Terjemahan Gunawan Hutauruk, Penerbit Erlangga, Jakarta.

Komaruddin, (2012),. Analisa Organisasi dan Manajemen, Jakarta : Rajawali Press.

Moekijat, (2011), Latihan dan Pengembangan Sumber Daya Manusia, Cetakan Keempat, Penerbit CV Bandar Maju, Bandung.

Mustika, I Ketut (2012). Analisis Budaya Organisasi dan Kepuasan Kerja Melalui Komitmen Pengaruhnya Terhadap Intent to Leave Karyawan pada Industri Jasa Perhotelan di Kabupaten Badung dan Kota Denpasar. Jurnal Mitra Ekonomi dan Manajemen Bisnis, Vol.3, No. 1, April 2012, 124 ISSN 2087-1090.

Pertiwi, Feni. (2017). Pengaruh Disiplin Kerja Terhadap Produktivitas Kerja Pegawai Negeri Sipil Di Kantor Dinas Perindustrian Perdagangan Koperasi Dan Umkm Provinsi Kalimantan Timur. eJournal Administrasi Negara. Volume 5 , Nomor 1, 2017: 5360 - 5374. ISSN 0000-0000.

Sarwoto, (2011), Dasar-dasar Oragnisasi dan Manajemen, Cetakan Kedelapan, Penerbit Ghalia Indonesia, Jakarta.

Schermenharn, John R. (2009), Manajemen, Yogyakarta : Penerbit Andi.

Siagian, Sondang P. (2007), Peranan Staf Dalam Manajemen, Cetakan Keempat, PT. Gunung Agung, Jakarta.

Soewarno, Handayaningrat, (2011),. Pengantar Studi Ilmu Administrasi dan Manajemen, Jakarta : Gunung Agung.

Suparyadi. (2015). Manajemen Sumber Daya Manusia. Yogyakarta: Andi Offset. Suwatno. (2013). Manajemen Sumber Daya Manusia. Penerbit Erlangga. Jakarta.

Tampubolon P. Manahan, (2014). Perilaku Keorganisasi. Jakarta : Ghalia Indonesia. 